\title{
Chapter 9 \\ Rice Straw Management Effects on Greenhouse Gas Emissions and Mitigation Options
}

\author{
Justin Allen, Kristine S. Pascual, Ryan R. Romasanta, Mai Van Trinh, \\ Tran Van Thach, Nguyen Van Hung, Bjoern Ole Sander, \\ and Pauline Chivenge
}

\begin{abstract}
Lowland rice is a significant source of anthropogenic greenhouse gas emissions (GHGEs) and the primary source of agricultural emissions for many developing countries in Asia. At the same time, rice soils represent one of the largest global soil organic carbon sinks. Straw management is a key factor in controlling the emissions and mitigation potential of rice primarily by affecting methane $\left(\mathrm{CH}_{4}\right)$ from anaerobic decomposition and carbon losses from burning. Achieving climatesmart management of rice while also improving yields and farm profits, however, is challenging due to economic-environmental trade-offs. This balance could be met with appropriate site-specific practices. This chapter discusses these straw management practices that affect yield-scaled GHGEs and mitigation options in different rice environments.
\end{abstract}

Keywords Greenhouse gas emissions $\cdot$ GHG $\cdot$ Mitigation $\cdot$ Rice straw

J. Allen $(\triangle) \cdot$ R. R. Romasanta $\cdot$ N. V. Hung $\cdot$ P. Chivenge International Rice Research Institute (IRRI), Los Baños, Laguna, Philippines e-mail: j.allen@irri.org; r.romasanta@irri.org; hung.nguyen@irri.org; p.chivenge@irri.org

K. S. Pascual

Philippine Rice Research Institute (PhilRice), Muñoz, Nueva Ecija, Philippines

M. Van Trinh

Institute of Agricultural Environment, Nam Tu Liem District, Hanoi, Vietnam

T. Van Thach

Dinh Thanh Agricultural Research Center (DTARC), Loc Troi Group, Hoa Tan Hamlet,

Thoai Son District, An Giang, Vietnam

B. O. Sander

International Rice Research Institute (IRRI), Tu Liem District, Hanoi, Vietnam

e-mail: b.sander@irri.org 


\subsection{Introduction}

Lowland rice is a major contributor to greenhouse gas emissions (GHGEs) accounting for $10 \%$ of global emissions from agriculture (FAO 2015). This number is even higher for Southeast Asia (SEA) where $90 \%$ of the world's rice is produced, making up $10-20 \%$ of the region's total anthropogenic emissions and $40-60 \%$ of its agricultural emissions (UNFCC 2019). Rice is one of the largest sources of anthropogenic $\mathrm{CH}_{4}\left(\mathrm{GWP}^{1}=28\right)$ and a major contributor of $\mathrm{N}_{2} \mathrm{O}(\mathrm{GWP}=265) \cdot \mathrm{CO}_{2}$ emissions from rice, although large, are considered net-neutral from photosynthesis according to the IPCC 2006 guidelines. $\mathrm{CH}_{4}$ accounts for around $65 \%$ of global $\mathrm{CO}_{2}$ eq emissions from lowland rice; largely from anaerobic decomposition of straw and crop residue under continuously flooded conditions. The remaining $35 \%$ of emissions from rice can be attributed mostly to $\mathrm{N}_{2} \mathrm{O}$ from soil $\mathrm{N}$ cycling of fertilizer and to a smaller extent $\mathrm{N}$ from crop residues (EPA 2013). Rice straw management is, therefore, an important factor in controlling GHGEs from lowland rice-cropping systems.

In addition to emissions, straw management plays an important role in global carbon cycles through soil organic carbon (SOC) sequestration. SOC is an important indicator of soil quality, which suggests its importance in improving farmer adaptation to climate change. It is estimated that rice soils contain the largest SOC stocks among croplands (IPCC 2007; Lal 2004). The potential SOC deposition from returning rice straw to the soil is significant as almost half of the total carbon in rice plant residue is within the straw and stubble (although root $\mathrm{C}$ contributes most SOC). The common, yet mostly banned, practice of straw burning reduces the SOC sequestration potential of fresh straw incorporation.

Although returning fresh straw to the field can increase SOC, its sequestration benefits may be outweighed by the increase in $\mathrm{CH}_{4}$ emissions when applied under flooded conditions due to anaerobic decomposition. Additionally, straw management practices that reduce emissions or improve sequestration are not always advantageous to crop yields. Striking a balance between emissions reduction, carbon sequestration, and crop yields is challenging, but may be achievable with optimal site-specific straw management. The efficiency of this balance can be quantified by yield-scaled emissions and mitigation or NGWP and GHGI, ${ }^{2}$ more broadly referred to as climate-smart agriculture (CSA). This chapter discusses in-field/offfield rice straw management options affecting CSA-burning, incorporation, com-

\footnotetext{
${ }^{1}$ Global warming potential (GWP) is a measure of how much heat a greenhouse gas traps in the atmosphere up to a specific time horizon, relative to carbon dioxide $\left(\mathrm{CO}_{2}\right)$.

${ }^{2} \mathrm{Net}$ global warming potential (NGWP) can be defined as the radiative properties of all the GHG emissions plus carbon fixation, expressed as $\mathrm{CO}_{2} \mathrm{eq} \mathrm{ha}^{-1} \mathrm{year}^{-1}$ (Robertson and Grace 2004), while greenhouse gas intensity (GHGI) defines the GWP per unit of crop yield (Mosier et al. 2006)
} 
posting, biochar, and others - under various rice production environments, such as water management, cropping system, and soil type.

\subsection{In-Field Straw Management Effects on Emissions and Mitigation}

\subsubsection{Burning}

Open-field burning of rice straw has well-known negative environmental and agronomic impacts due to atmospheric pollution and reduced soil quality. Burning also emits GHGs $\mathrm{CO}_{2}, \mathrm{CH}_{4}$, and $\mathrm{N}_{2} \mathrm{O}$, along with other trace gases that contribute to tropospheric ozone and the formation of Atmospheric Brown Cloud (ABC) - a cause of severe human health concern (Arai et al. 1998; Gullett and Touati 2003; Lin et al. 2007; Tipayarom and Kim Oanh 2007; Torigoe et al. 2000; Kanokkanjana et al. 2011). Still, studies suggest that the total GHGEs from burning are up to $98 \%$ lower than those from fresh straw incorporation in flooded soils due to reductions in $\mathrm{CH}_{4}$ from straw decomposition (IPCC 2006). This accounting, however, excludes $\mathrm{CO}_{2}$ emissions, which are considered net neutral from photosynthesis in the IPCC guidelines. When $\mathrm{CO}_{2}$ is included, the carbon losses from burning reduce the SOC sequestration potential of fresh straw incorporation due to the immediate $90 \%$ loss of straw $\mathrm{C}$ as $\mathrm{CO}_{2}$ during combustion (Chen et al. 2019). When this is accounted for, the NGWP from burning is comparable to that of complete fresh straw incorporation (Lu et al. 2010).

SOC sequestration is thus an important component of emissions calculations from burning. For example, a meta-analysis in China compared the effects of burning and straw incorporation on NGWP to include sequestration and found that switching from burning to straw incorporation could mitigate $34.18 \mathrm{Mt} . \mathrm{CO}_{2}$ eq year $^{-1}$ or $31 \%$ of total rice emissions in the country (Lu 2015; Liu et al. 2014). This assumed a large sequestration potential by restoring degraded soils to their maximum SOC storage ability or SOC saturation capacity (EPA 2013). Once saturation was reached, the mitigation potential of straw incorporation diminished. Increasing SOC not only mitigates emissions, but can also substantially improve soil quality, yields, and adaptation to climate change by improving drought tolerance. For example, an only $1 \%$ improvement to SOM can double the soil water holding capacity (Fileccia et al. 2014).

Despite the established negative long-term impacts of burning on soil quality, SOC sequestration and air quality, intensive rice farmers prefer burning rice straw due to lower costs, reduced weed and disease carryover, and ease of tillage. Advantages of burning may decline as opportunities increase for off-farm uses and stricter government environmental regulations encourage alternative options. 


\subsubsection{Incorporation Rates and Environmental Factors}

\subsubsection{Water Management}

$\mathrm{CH}_{4}$ emissions from rice are highly dependent on the amount of straw or crop residue returned under continuously flooded conditions (Liu et al. 2014). Because of this, removing rice straw in flooded rice is considered a mitigation strategy that could theoretically reduce the GWP of emissions from rice by $45 \%$ (Wang et al. 2016). The benefits of complete straw removal on reducing emissions, however, are offset by reduced SOC sequestration, soil quality, and long-term yields. Maximum emission reductions and yield (and SOC deposition) may be best achieved by partial straw return/removal in most continuous rice systems (Romasanta et al. 2017). This balance can still increase SOC storage over time and provide adequate crop nutrients. Because straw decomposition rates, and thus emissions, depend on climate, cropping system, and soil type, these factors can help determine the appropriate percentage of straw to return. Generally, soils that are well-drained or have low SOC with aerobic periods benefit from increased straw return to maximize SOC sequestration and increase yields with minimal $\mathrm{CH}_{4}$ emissions, i.e., the percentage of straw returned should be approximately proportional to the percentage of time under aerobic conditions (Monteleone et al. 2015).

Controlling the aerobic condition of paddy soil is primarily achieved by irrigation management. The use of non-flooded, aerobic periods to reduce $\mathrm{CH}_{4}$ from organic matter decomposition in rice is a well-established mitigation strategy called alternate wetting and drying (AWD) that can reduce emissions in lowland irrigated rice by $48 \%$ on average (IRRI 2016). AWD will be an increasingly important strategy to mitigate future emissions of $\mathrm{CH}_{4}$ as expanding combine harvester use promotes straw incorporation. Reduced flooding can also be achieved with the use of laser land-levelling, dry direct-seeded rice, and short-duration rice varieties. These methods are well established water-saving practices described in previous studies (Monteleone et al. 2015; Bouman et al. 2007). Reduced flooding affects emissions by shifting from anaerobic to aerobic microbial respiration to produce $\mathrm{CO}_{2}$ in place of $\mathrm{CH}_{4}$. Although $\mathrm{CO}_{2}$ emissions increase under aerobic conditions, the effect on GWP is much lower than $\mathrm{CH}_{4}$. Additionally, aerobic decomposition of residue improves SOM conversion to more stabilized forms of SOC that have a lower additive effect on $\mathrm{CH}_{4}$ once flooded (Jiang et al. 2019).

Despite the benefits of aerobic regimes on emissions from rice straw, it comes with an increased risk of SOC loss compared to continuous flooding. Additionally, $\mathrm{N}_{2} \mathrm{O}$ emissions may be significant during dry conditions - although $\mathrm{N}_{2} \mathrm{O}$ emissions are largely an effect of fertilizer, as straw supplies only around $10 \%$ of $\mathrm{N}$ in intensive systems (Yadvinder-Singh et al. 2004; Eagle et al. 2001). In more aerobic rice systems, $\mathrm{N}_{2} \mathrm{O}$ emissions can be mitigated by proper nutrient management, and SOC losses can be compensated for by increasing the rate of straw return. 


\subsubsection{Cropping System}

As with irrigation management, the type of cropping system is an important factor in controlling soil conditions and emissions from rice straw. Because fallow conditions and upland crops mostly eliminate anaerobic conditions for $\mathrm{CH}_{4}$ production, the emissions from aerobic decomposition $\left(\mathrm{N}_{2} \mathrm{O}, \mathrm{CO}_{2}\right)$ and loss in $\mathrm{SOC}$ can be significant. For example, SOC levels in a long-term rice-maize rotation at IRRI were $14 \%$ lower than that of continuous rice (Witt et al. 2000). For this reason, intensive rice-upland cropping systems may require complete straw return to the upland crop to prevent SOC depletion.

\subsubsection{Tillage}

Tillage type and timing can greatly affect emissions from straw returned to the field. When straw is chopped and incorporated into the soil at least 30 days before flooding, rice $\mathrm{CH}_{4}$ emissions have been shown to be reduced by up to $80 \%$ (Launio et al. 2013; Kajiura et al. 2018). Reduction $\mathrm{CH}_{4}$ emissions can be attributed to the increased aerobic decomposition of straw to stabilized SOM before flooding. Due to the additional benefits of early incorporation to planting and soil quality, it is considered a CSA priority for flooded rice. In fact, studies show early incorporation is one the most cost-effective, climate-smart rice straw management options (Launio et al. 2016).

When residue is removed, tillage has shown to increase emissions and reduce SOC in rice. A meta-analysis on 48 studies on continuous rice in China showed that no-till reduced the GWP from $\mathrm{CO}_{2}$ and $\mathrm{CH}_{4}$ by $20.4 \%$ when straw was removed, but had no significant effect when straw was returned (Feng et al. 2018; Huang et al. 2018).

In upland crops after rice, no-tillage with full straw returned is an established CSA strategy for many rice-upland environments (Grace et al. 2012). A study on marginal abatement costs suggest that no-till accounted for $70 \%$ of the cost-effective GHG mitigation potential in 2010 across non-rice crops (EPA 2013). The effects of no-till and straw mulching on yield, GHG emissions, and soil quality are most pronounced in rainfed, light textured soils. In fact, no-till for the rice-wheat rotation is credited as one of the greatest resource-saving technologies for the Indo-Gangetic Plains (Erenstein 2009; Zandstra 1982). Tillage is shown to stimulate mineralization and oxidation of SOM in aerobic soils, causing a reduction in SOC and increase in $\mathrm{N}_{2} \mathrm{O}$ emissions. These effects have been established in many meta-analyses (Zhao et al. 2015; Feng et al. 2018; Lu 2015; Liu et al. 2014). Therefore, the optimal tillage management for CSA in rice-upland systems is often complete straw returned as mulch with no-till in the upland crop followed by early residue incorporation or removal before flooded rice. 


\subsubsection{Soil Type}

Emissions and mitigation from rice straw management are highly dependent on soil type (Badagliacca et al. 2017). A meta-analysis of GHGE studies across Japan showed that $\mathrm{CH}_{4}$ emissions significantly varied by soil type by as much as $200 \%$ (Kajiura et al. 2018). Still, the soil properties that stimulate $\mathrm{CH}_{4}$ emissions from straw incorporation are not well understood. Conditions known to stimulate methanogenesis are a soil redox potential below $-200 \mathrm{mV}$ and neutral $\mathrm{pH}$. It can be assumed that the variability in $\mathrm{CH}_{4}$ production by soil type may be related to differences in soil nutrients. Some studies suggest that high levels of ammonia and sulfates are known to inhibit methanogenesis (Sánchez et al. 2015).

The ability of straw incorporation to improve SOC sequestration is also affected by soil type. Generally, soils which have been depleted of SOC and contain high clay or oxygen-reduced conditions can store more C. It is estimated that returning crop residues to these soils along with proper CSA management could help sequester enough SOC to offset the current increase in emissions from all anthropogenic sources (White 2017).

\subsubsection{Fertilizer}

Studies suggest there is a significant interaction effect of rice straw management and fertilizer on GHGEs. Yet, the degree of this effect is complex and thus difficult to form conclusions on management recommendations. $\mathrm{N}_{2} \mathrm{O}$ emissions from the application of organic and inorganic fertilizers are, however, an important topic as they represent $5 \%$ of global anthropogenic emissions (IPCC 2007). Although $\mathrm{N}_{2} \mathrm{O}$ is considered negligible during most rice production, which is flooded or kept saturated, trends towards more aerobic rice systems due to water limitations and increasing upland crop rotation make $\mathrm{N}_{2} \mathrm{O}$ a concern. A meta-analysis on 112 assessments showed that straw incorporation can reduce $\mathrm{N}_{2} \mathrm{O}$ emissions from fertilizer by $27 \%$ in rice, although straw incorporation alone generally increased $\mathrm{N}_{2} \mathrm{O}$ due to the inherent $\mathrm{N}$ content of straw (Shan and Yan 2013). There is also evidence that $\mathrm{CH}_{4}$ emissions from straw incorporation are affected by fertilizer. A meta-analysis of 155 data pairs showed that $\mathrm{N}$ fertilizer stimulated $\mathrm{CH}_{4}$ emissions in $64 \%$ of cases and the stimulatory effect of $\mathrm{N}$ fertilizer on $\mathrm{CH}_{4}$ was two to threefold greater with urea than with ammonium sulphate (Banger et al. 2012). 


\subsection{Off-Field Straw Management Effects on GHGEs}

\subsubsection{Composting}

Straw composting with manure can be an effective option to reduce $\mathrm{CH}_{4}$ emissions associated with in-field straw incorporation along with $\mathrm{CH}_{4}$ and $\mathrm{N}_{2} \mathrm{O}$ emissions from manure management. Manure management accounts for $11 \%$ of global agricultural emissions, thus is an equally important GHG source as lowland rice. Emissions from manure are mainly in the form of $\mathrm{CH}_{4}$ from anaerobic settling ponds $(23 \%)$ and $\mathrm{N}_{2} \mathrm{O}$ from manure applied to soils and dry storage $(77 \%)$ (FAO 2017).

Aerobic composting is an effective method to reduce methanogenesis of $\mathrm{CH}_{4}$ from anaerobic manure storage in settling ponds. Studies suggest aerated manure with straw can reduce $\mathrm{CH}_{4}$ emissions up to $90 \%$ compared to anaerobic storage (Petersen et al. 2013). The effects of composting on $\mathrm{N}_{2} \mathrm{O}$ emissions from manure are, however, more complex than $\mathrm{CH}_{4} \cdot \mathrm{N}_{2} \mathrm{O}$ is emitted indirectly from manure mainly by $\mathrm{NH}_{3}$ volatilization, which converts to $\mathrm{N}_{2} \mathrm{O}$ in the atmosphere. Smaller, but additional $\mathrm{N}$ losses can occur from $\mathrm{NO}_{3}$ leaching/erosion, which also convert to $\mathrm{N}_{2} \mathrm{O}$. Improper field application of manure or composting can cause an almost $100 \%$ loss of manure $\mathrm{N}$ to the atmosphere affecting both GHGEs and $\mathrm{N}$ supply value if used for fertilizer. This often occurs when manure is applied to soils with high $\mathrm{pH}$ and low $\mathrm{CEC}$, and without injection/incorporation. In this scenario, composting manure with rice straw could provide substantial emissions mitigation.

Rice straw is an ideal bulking agent for manure compost due to its high C:N ratio, which can help maintain the ideal 25:1 of the compost. This $\mathrm{C}: \mathrm{N}$ ratio maximizes $\mathrm{N}$ immobilization and substrate adsorption, which minimizes losses by volatilization and leaching. $\mathrm{N}$ losses from proper composting may be as low as $13 \%$ of the original feedstock $\mathrm{N}$ (Chadwick et al. 2011). The opportunity to mitigate $\mathrm{N}_{2} \mathrm{O}$ from composting, however, may be fairly small given many farms can avoid $100 \%$ $\mathrm{N}$ loss by injecting/incorporating manure or applying it directly to soils with high $\mathrm{CEC}$, clay, or low $\mathrm{pH}$. In this case, the mitigation opportunity of straw/manure compost may be primarily through avoiding $\mathrm{CH}_{4}$ emissions from anaerobic manure storage and in-field rice straw incorporation, along with the potential indirect abatement of emissions from $\mathrm{N}$ fertilizer production (Chen et al. 2011). An additional, yet understudied, effect of rice straw composting vs. in-field incorporation may come from increased SOC sequestration. Although studies are limited, some suggest composting increases the stabilized fraction of SOC and sequesters more carbon compared to in-field aerobic decomposition of residue (Spaccini and Piccolo 2017). 
The added step of producing mushrooms from straw compost could theoretically reduce $\mathrm{N}_{2} \mathrm{O}$ emissions further by increasing $\mathrm{N}$ immobilization through mushroom nutrient uptake, although this has not been established. Studies do suggest that infield emissions of $\mathrm{CH}_{4}$ can be substantially mitigated by incorporating spent mushroom compost to the field in place of fresh rice straw. One study in the Philippines estimated $\mathrm{CH}_{4}$ emissions from mushroom production at only $73 \mathrm{~g} \mathrm{CH}_{4} \mathrm{t}^{-1}$ of straw (dry weight) compared to the IPCC default emission factor of $4 \mathrm{~kg} \mathrm{CH}_{4} \mathrm{t}^{-1}$ for straw manure compost (Truc 2011). Arai et al. (2015) also found that the total GWP in straw-mushroom cultivation is $12.5 \%$ lower than straw burning.

\subsubsection{Biochar}

Like compost, biochar can mitigate the $\mathrm{CH}_{4}$ emissions associated with fresh straw incorporation by providing an off-field use for straw. The total mitigation potential of biochar, however, extends beyond compost due to its ability to improve sequestration by converting straw to a more stabilized form of C (Yin et al. 2014). Studies on $C$ cycling of crop residue suggest that incorporation and composting lose 80-90\% of the initial carbon as $\mathrm{CO}_{2}$ during decomposition in the first 5-10 years. In contrast, about $50 \%$ of the carbon can be captured as stable SOC when residue is converted to biochar (Lehmann et al. 2006)

Biochar blended with manure/straw compost has also been shown to substantially reduce $\mathrm{N}$ losses during the composting process due to its effect on nutrient sorption. Like straw, biochar can increase the adsorption of $\mathrm{N}$ and prevent $\mathrm{NH}_{3}$ volatilization and this effect from biochar can be many times greater than that of straw due its high adsorption capacity or CEC. Studies on compost showed total N losses could be reduced by $52 \%$ with the addition of biochar (Steiner et al. 2010).

When biochar is returned to the field, its effects on total GHGEs; however, are mixed - possibly due to the variable quality of biochar products and dynamic conditions of soil. A meta-analysis of 61 studies on biochar of various feedstocks showed that GHGEs in paddy rice were: $-5 \%$ for $\mathrm{CO}_{2},-20 \%$ for $\mathrm{N}_{2} \mathrm{O}$, but $+19 \%$ for $\mathrm{CH}_{4}$ $(\mathrm{P}<0.05)$ with the addition of biochar (Song et al. 2016). Conversely, another metaanalysis of 42 studies showed that biochar reduced $\mathrm{CH}_{4}$ in acidic soils (Jeffrey et al. 2016). $\mathrm{A} \mathrm{CH}_{4}$ reduction along with a 50-70\% reduction in the total $\mathrm{C}$ footprint for rice production was also reported in a life cycle assessment study comparing openfield straw burning to straw biochar (Mohammadi et al. 2016). A meta-analysis of 29 studies comparing biochar effects among cropping systems showed that biochar reduced GHGI (yield-scaled emissions) by $41 \%$ in upland soils and $17 \%$ in paddy soils (Liu et al. 2019). 
In light of those studies with large emissions reductions, some authors suggest biochar could potentially mitigate emissions of $\mathrm{CO}_{2}, \mathrm{CH}_{4}$, and $\mathrm{N}_{2} \mathrm{O}$ by a maximum of $1.8 \mathrm{Pg} \mathrm{CO}_{2}$ eq year ${ }^{-1}$ (12\% of current anthropogenic $\mathrm{CO}_{2}$ eq emissions; $1 \mathrm{Pg}=1$ $\mathrm{Gt}$ ), and total net emissions over the course of a century by $130 \mathrm{Pg} \mathrm{CO}_{2}$ eq (Das et al. 2014). Theoretically, this makes biochar one of the top mitigation options for rice straw management. Still, more evidence is needed on the feasibility of biochar in CSA, especially as many studies suggest it is cost-prohibitive due to the large volume (around $6 \mathrm{t} \mathrm{ha}^{-1}$ ) of biochar needed in-field to achieve mitigation.

\subsection{Other Off-Field Practices and Effects on GHGEs}

\subsubsection{Mechanized Straw Collection}

The use of combine harvesters for rice has expanded rapidly worldwide, and major producers such as Vietnam and Cambodia almost exclusively rely on them (Gummert et al. 2018). This has large implications for rice straw management and its associated indirect and direct effects on GHG emissions. Contrary to traditional harvesting systems that use threshers and pile straw for easy collection, combine harvesters spread rice straw on the field. This hampers manual collection, thus promoting straw incorporation and increased $\mathrm{CH}_{4}$ emissions. Additionally, the added emissions from fuel consumption and machine production range around $60-165 \mathrm{~kg} \mathrm{CO}_{2}$ eq $\mathrm{t}^{-1}$ of collected straw (Nguyen et al. 2016).

\subsubsection{Fodder}

Enteric fermentation as $\mathrm{CH}_{4}$ from livestock is the leading source of agricultural emissions and accounts for about 5.8\% of total anthropogenic emissions (Gerber et al. 2013). The quality of ruminant feed has a significant effect on this emission intensity. Rice straw fodder, although used widely across Asia, is particularly inefficient as a ruminant feed. Its low digestibility equates to high yield-scaled $\mathrm{CH}_{4}$ emissions compared to more high-quality fodder, such as cowpea straw (Hristov et al. 2013). In fact, rice straw as fodder has been shown to increase GWP 13\% compared to straw burning (Launio et al. 2016). Because of the widespread use of rice straw as fodder, it can be assumed that its contribution to emissions from enteric fermentation is significant. Improving the digestibility of poor-quality fodder, such as rice straw, may be one of the most effective emissions mitigation strategies for 
livestock according to Gerber et al. (2013). Research suggests that the digestibility of rice straw could be improved by up to $20 \%$ by pretreatment methods, such as nutrients and inoculants (Sarnklong et al. 2010). In cattle, a 1\% increase in straw digestibility equates to a $4 \%$ increase in growth rate and proportional drop in yieldscaled emissions.

\subsubsection{Bioenergy}

\subsubsection{Straw Combustion for Thermal Bioenergy}

Rice straw can serve as a low-cost and renewable fuel source for combustion power plants. According to LCA on the use of rice straw as thermal bioenergy in Thailand, emissions can be reduced by $1.79 \mathrm{~kg} \mathrm{CO}_{2}$ eq $\mathrm{kWh}^{-1}$ compared to coal power and $1.05 \mathrm{~kg} \mathrm{CO}_{2}$ eq $\mathrm{kWh}^{-1}$ compared to natural gas-based power generation. Delivand et al. (2011) found that substituting natural gas or coal fuels with rice straw fuels for power generation would result in a considerable fossil fuel savings and lower GHGEs. It was estimated that $0.378 \mathrm{tCO}_{2} \mathrm{eq} \mathrm{t}^{-1}$ straw and $0.683 \mathrm{tCO}_{2}$ eq $\mathrm{t}^{-1}$ straw could be avoided if rice straw substitutes natural gas or coal in the power generation sector, respectively.

\subsubsection{Straw Anaerobic Digestion for $\mathrm{CH}_{4}$ Bioenergy}

Agricultural residues, such as rice straw, offer a valuable alternative feedstock for biogas production since they contain a considerable amount of carbon that is beneficial for anaerobic codigestion with animal manure (Mussoline et al. 2012). Anaerobic digestion (see more details in Chap. 5) is a biological process that can degrade waste organic material by the concerted action of a wide range of microorganisms in the absence of oxygen. The process converts a large portion of rice straw into biogas, which is typically a mixture of methane $(60 \%)$ and carbon dioxide (40\%). If captured, biogas can be utilized as a clean fuel for heat and power generation. In principle, anaerobic digestion is an attractive option for mitigating the $\mathrm{CH}_{4}$ associated with straw incorporation. However, in actual practice, particularly for small-scale anaerobic digestion, the technology has not proven efficient enough to be the most feasible mitigation strategy. Improving the technology to reduce leakage and match the digester capacity to biogas use in small-scale applications may be required to be a viable mitigation option.

Regarding the use of rice straw for bio-ethanol production, a review by Cheng and Timilsina (2011) reported that all advanced biofuel technologies have the advantage of producing fuels with almost zero or very little net emissions to the atmosphere. 


\subsection{Conclusions and Recommendations}

Lowland rice contributes $10 \%$ of the global agricultural GHGEs due to $\mathrm{CH}_{4}$ production from anaerobic decomposition of organic material. Straw management is therefore a key factor for controlling global agricultural emissions. Incorporating rice straw under flooded conditions leads to high $\mathrm{CH}_{4}$ emissions. Burning, although a standard practice with lower GHGEs than incorporating, is not considered a CSA option due to its negative effect on soil nutrients, SOC, and air pollution. Water management through AWD is a major GHG mitigation strategy that can reduce $48 \%$ of the $\mathrm{CH}_{4}$ and thus is an effective method to reduce emissions when straw is incorporated under flooded conditions. AWD in combination with early incorporation can further reduce $\mathrm{CH}_{4}$ emissions by $80 \%$. The rate of straw incorporation to achieve CSA, however, is highly dependent on environment. Rice-upland crop rotations or rice systems with prolonged fallow periods benefit from greater rates of straw incorporation due to losses in SOC. High rates of straw incorporation under aerobic conditions can sequester SOC with a minimal increase in emissions compared to incorporation under flooded conditions. Practices that optimize SOC sequestration while minimizing emissions, such as early straw incorporation with AWD water management could be an important step towards carbon neutral rice systems.

Off-field practices such as composting, biochar, and bioenergy offer potentially larger mitigation opportunities than in-field practices. Composting, for example, can mitigate both emissions associated with fresh straw incorporation and those associated with livestock manure and fertilizer use. The combination of biochar and compost can further enhance mitigation. Although effective, off-field technologies may be limited due to the added costs of straw transport, capital equipment and labor.

Depending on site-specific conditions related to economics, climate, soil type, and infrastructure, a combination of off-field and in-field straw management practices is needed to reduce emissions from rice production. More holistic and crosssectoral studies, e.g., through life-cycle assessment, are needed to determine the full GHG budget of certain site-specific straw management options. Additionally, MACC and CBA studies would be important to develop clear technical and policy recommendations that also consider the economics of CSA and straw management.

\section{References}

Arai T, Takaya T, Ito Y, Hayakawa K, Tshima S, Shibuya C, Nomura M, Yoshimi N, Hibayama M, Yasuda Y (1998) Bronchial asthma induced by rice. Intern Med 37:98-101

Arai H, Hosen Y, Pham Hong VN, Thi NT, Huu CN, Inubushi K (2015) Greenhouse gas emissions from rice straw burning and straw-mushroom cultivation in a triple rice cropping system in the Mekong Delta. Soil Sci Plant Nutr 61:719-735 
Badagliacca G, Ruisi P, Rees RM, Sergio S (2017) An assessment of factors controlling $\mathrm{N}_{2} \mathrm{O}$ and $\mathrm{CO}_{2}$ emissions from crop residues using different measurement approaches. Biol Fertil Soils 53:547

Banger K, Tian H, Lu C (2012) Do nitrogen fertilizers stimulate or inhibit methane emissions from rice fields? Glob Chang Biol 18:3259-3267

Bouman BAM, Lampayan RM, Tuong TP (2007) Water Management in Irrigated Rice: coping with water scarcity. Intl Rice Res Inst, Los Baños, p 54

Chadwick D, Sommer SG, Thorman R, Fangueiro D, Cardenas L, Amon B, Misselbrook T (2011) Manure management: implications for greenhouse gas emissions. Anim Feed Sci Technol 166-167:514-531

Chen J, Gong Y, Wang S, Guan B, Balkovic J, Kraxner F (2019) To burn or retain crop residues on croplands? An integrated analysis of crop residue management in China. Sci Total Environ 662:141-150

Chen R, Lin x WY, Hu J (2011) Mitigating methane emissions from irrigated paddy fields by application of aerobically composted livestock manures in eastern China. Soil Use Manag 27:103-109

Cheng JJ, Timilsina GR (2011) Status and barriers of advanced biofuel technologies: a review. Renew Energy 36:3541-3549

Das S, Avasthe R, Singh R, Babu S (2014) Biochar as carbon negative in carbon credit under changing climate (vol 107)

Delivand MK, Barz M, Gheewala SH (2011) Logistics cost analysis of rice straw for biomass power generation in Thailand. Energy 36:1435-1441

Eagle AJ, Bird BA, Horwath WR, Linquist BA, Brouder SM, Hill JE, Van Kessel C (2001) Rice yield and nitrogen utilization efficiency under alternative straw management practices. Agron J 92:1096-1103

Erenstein O (2009) Zero tillage in the rice-wheat systems of the Indo-Gangetic plains: A review of impacts and sustainability implications. IFPRI Discussion Paper 00916. International Food Policy Research Institute, Washington

EPA (US Environmental Protection Agency) (2013) Global mitigation of Non- $\mathrm{CO}_{2}$ greenhouse gases, 2010-2030.Washington, DC. https://www.epa.gov/sites/production/files/2016-06/documents/mac_report_2013.pdf

FAO (Food and Agriculture Organization) (2015) Estimating greenhouse gas emissions in agriculture: a manual to address data requirements for developing countries. Food and Agriculture Organization of the United Nations, Rome

FAO (Food and Agriculture Organization) (2017) Global Livestock Environmental Assessment Model (GLEAM) http://www.fao.org/gleam/results/en/

Feng J, Li F, Zhou X, Xu C, Ji L, Chen Z, Fuping F (2018) Impact of agronomy practices on the effects of reduced tillage systems on $\mathrm{CH}_{4}$ and $\mathrm{N}_{2} \mathrm{O}$ emissions from agricultural fields: a global meta-analysis. PLoS One 13(5):e0196703

Fileccia T, Guadagni M, Hovhera V, Bernoux M (2014) Ukraine: soil fertility to strengthen climate resilience preliminary assessment of the potential benefits of conservation agriculture. Food and Agriculture Organization of the United Nations, Rome

Gerber PJ, Steinfeld H, Henderson B, Mottet A, Opio C, Dijkman J, Falcucci A, Tempio G (2013) Tackling climate change through livestock: a global assessment of emissions and mitigation opportunities. Food and Agriculture Organization of the United Nations, Rome

Grace PR, Antle J, Aggarwal PK, Ogle S, Paustian K, Basso B (2012) Soil carbon sequestration and associated economic costs for farming systems of the indo-Gangetic plain: a meta-analysis. Agric Ecosyst Environ 146:137-146

Gullett B, Touati A (2003) PCDD/F emissions from burning wheat and Rice field residue. Atmos Environ 37:4893-4899

Gummert M, Quilty J, Hung NV, Vial L (2018) Engineering and management of rice harvesting. In: Pan Zhongli Khir R Advances in science \& engineering of rice Destech Publication Pennsylvania 
Hristov AN, Oh J, Lee C, Meinen R, Montes F, Ott T, Firkins J, Rotz A, Dell C, Adesogan A, Yan W, Tricarico J, Kebreab E, Waghorn G, Dijkstra J, Oosting S (2013) Mitigation of greenhouse gas emissions in livestock

Huang Y, Ren W, Wang L, Hui D, Grove JH, Yang X, Tao B, Goff B (2018) Greenhouse gas emissions and crop yield in no-tillage systems: a meta-analysis. Agric Ecosyst Environ Appl Soil Ecol 268:144-153

IRRI (International Rice Research Instititute) (2016) Overview of AWD. http://books.irri.org/ AWD_brochure.pdf

IPCC (Intergovernmental Panel on Climate Change) (2006) IPCC guidelines for national greenhouse gas inventories. Prepared by the National Greenhouse Gas Inventories Programme, Eggleston HS, Buendia L, Miwa K, Ngara T, Tanabe K (eds) IGES: Japan

IPCC (Intergovernmental Panel on Climate Change) (2007) Climate change 2007: the physical science basis summary for policymakers. Contribution of working group I to the fourth assessment report of the intergovernmental panel on climate change. In: Solomon S, Qin D, Manning M, Chen Z, Marquis M, Averyt KB, Tignor M, Miller HL, eds. Cambridge University Press, New York

Jeffrey S, Verheijen FGA, Kammann C, Abalos D (2016) Biochar effects on methane emissions from soils: a meta-analysis. Soil Biol Biogeochem 101:251-258

Jiang Y, Qian H, Huang S, Zhang X, Wang L, Zhang L, Shen M, Xiao X, Chen F, Zhang H, Lu C, Li C, Zhang J, Deng A, van Groenigen KJ, Zhang W (2019) Acclimation of methane emissions from rice paddy fields to straw addition. Sci Adv 5:eaau9038

Kajiura M, Minamikawa K, Tokida T, Shirato Y, Wagai R (2018) Methane and nitrous oxide emissions from paddy fields in Japan: an assessment of controlling factors using an intensive regional data set. Agric Ecosyst Environ 252:51-60

Kanokkanjana K, Cheewaphongphan P, Garivait S (2011) Black carbon emission from paddy field open burning in Thailand. IPCBEE Proc 6:88-92

Lal R (2004) Soil carbon sequestration impacts on global climate change and food security. Science 304:1623-1627

Launio CC, Asis CA, Manalili RG, Javier EF (2013) Economic analysis of rice straw management alternatives and understanding farmers' choices. EEPSEA Research Report rr2013031, Economy and Environment Program for Southeast Asia. https://ideas.repec.org/p/eep/report/ rr2013031.html

Launio CC, Asis CA, Manalili RG, Javier EF (2016) Cost-effectiveness analysis of farmers' rice straw management practices considering $\mathrm{CH}_{4}$ and $\mathrm{N}_{2} \mathrm{O}$ emissions. $\mathrm{J}$ Environ Manag 183:245-252

Lehmann J, Gaunt J, Rondon M (2006) Bio-char sequestration in terrestrial ecosystems: a review. Mitig Adapt Strat Glob Change 11:403-427

Lin LF, Lee WJ, Li HW, Wang MS, Chang-Chien GP (2007) Characterization and inventory of $\mathrm{PCDD} / \mathrm{F}$ emissions from coal-fired power plants and other sources in Taiwan. Chemosphere 68:1642-1649

Liu C, Lu M, Cui J, Li B, Fang C (2014) Effects of straw carbon input on carbon dynamics in agricultural soils: a meta-analysis. Glob Chang Biol 20:1366-1381

Liu X, Mao P, Li L, Ma J (2019) Impact of biochar application on yield-scaled greenhouse gas intensity: a meta-analysis. Sci Total Environ 656:969-976

Lu F (2015) How can straw incorporation management impact on soil carbon storage? A metaanalysis. Mitig Adapt Strateg Glob Change 20:1545

Lu F, Wang X, Han B, Ouyang Z, Duan X, Zheng H (2010) Net mitigation potential of straw return to Chinese cropland: estimation with a full greenhouse gas budget model. Ecol Appl 20(3):634-647

Mohammadi A, Cowie A, Anh Mai TL, de la Rosa RA, Kristiansen P, Brandão M, Joseph S (2016) Biochar use for climate-change mitigation in rice cropping systems. J Clean Prod 116:61-70

Monteleone M, Garofalo P, Cammerino ARB, Libutti A (2015) Cereal straw management: a tradeoff between energy and agronomic fate. Ital J Agron 10(2):59-66 
Mosier AR, Halvorson AD, Reule CA, Liu XJ (2006) Net global warming potential and greenhouse gas intensity in irrigated cropping systems in northeastern Colorado. J Environ Qual 35:1584-1598

Mussoline W, Esposito G, Giordano A, Lens P (2012) Anaerobic digestion of rice straw: a review. Crit Rev Environ Sci Technol 43(9):895-915

Nguyen H, Nguyen C, Tran T, Hau H, Nguyen N, Gummert M (2016) Energy efficiency, greenhouse gas emissions, and cost of rice straw collection in the mekong river delta of Vietnam. Field Crop Res 198:16-22

Petersen SO, Blamchard M, Chadwick D, Del Prado A, Edourd N, Mosquera J, Sommer SG (2013) Manure management for greenhouse gas mitigation. Animal 7 (s2):266-282

Robertson GP, Grace PR (2004) Greenhouse gas fluxes in tropical and temperate agriculture: the need for a full-cost accounting of global warming potentials. Environ Dev Sustain 6:51-63

Romasanta RR, Sander OB, Gaihre YK, Alberto MC, Gummert M, Quilty J, Nguyen VH, Castalone AG, Balingbing C, Sandro K, Correa T, Wassmann R (2017) How does burning of rice straw affect $\mathrm{CH}_{4}$ and $\mathrm{N}_{2} \mathrm{O}$ emissions? A comparative experiment of different on-field-straw management practices. Agric Ecosyst Environ 239:143-154

Sánchez A, Artola A, Font X, Gea T, Barrena R, Gabriel D, Monedero MAS, Roig A, Cayuela ML, Mondin C (2015) Greenhouse Gas from Organic Waste Composting: Emissions and Measurement. In: Lichtfouse E, Schwarzbauer J, Robert D (eds) CO2 sequestration, biofuels, and depollution. Environmental chemistry for a sustainable world. vol 5. Springer, Berlin

Sarnklong C, Cone JW, Pellikaan W, Hendriks WH (2010) Utilization of rice straw and different treatments to improve its feed value for ruminants: a review. Asian-Aust J Anim Sci 23(5):680-692

Shan J, Yan XY (2013) Effects of crop residue returning on nitrous oxide emissions in agricultural soils. Atmos Environ 71:170-175

Song X, Pan G, Zhang C, Zhang L, Wang H (2016) Effects of biochar application on fluxes of three biogenic greenhouse gases: a meta-analysis. Ecosyst Health Sustain 2:2. https://doi. org/10.1002/ehs 2.1202

Spaccini R, Piccolo A (2017) Soil organic carbon stabilization in compost amended soils. Global Symposium on Soil Organic Carbon. 21-23 March 2017. Rome, Italy

Steiner C, Das KC, Melear N, Lakly D (2010) Reducing nitrogen loss during poultry litter composting using biochar. J Environ Qual 39:1236-1242. https://doi.org/10.2134/jeq2009.0337

Tipayarom D, Kim Oanh NT (2007) Effects from open rice straw burning emission on air quality in the Bangkok metropolitan region. Sci Asia 33:339-345

Torigoe K, Hasegawa S, Numata O, Yazaki S, Matsumaga M, Boku N, Hiura M, Ino H (2000) Influence of emission from rice straw burning on bronchial asthma in children. Pediatr Int 42:143-150

Truc N (2011) Comparative assessment of using rice straw for rapid composting and straw mushroom production in mitigation greenhouse gas emissions in Mekong Delta, Vietnam and Central Luzon, Philippines. Unpublished PhD thesis. University of the Philippines Los Baños

UNFCC (United Nations Framework Convention on Climate Change) (2019). http://di.unfecc.int/ ghg_profile_non_annex 1

Wang W, Wu X, Chen A, Xie X, Wang Y, Yin C (2016) Mitigating effects of ex situ application of rice straw on $\mathrm{CH}_{4}$ and $\mathrm{N}_{2} \mathrm{O}$ emissions from paddy-upland coexisting system. Sci Rep 6:37402

White J (2017).Gathering momentum around soil carbon sequestration. https://ccafs.cgiar.org/ blog/gathering-momentum-around-soil-carbon-sequestration\#.XOSZS1IzbIU\%20IPCC, \%20 2007

Witt C, Cassman KG, Olk DC, Biker U, Liboon SP, Samson MI, Ottow JCG (2000) Crop rotation and residue management effects on carbon sequestration, nitrogen cycling and productivity of irrigated rice systems. Plant Soil 225:263 
Yadvinder-Singh B-S, Ladha JK, Khind CS, Khera TS, Bueno CS (2004) Effects of residue decomposition on productivity and soil fertility in fice-wheat rotation. Soil Sci Soc Am J 68:854-864

Yin YF, He XH, Gao R, Ma HL, Yang YS (2014) Effects of rice straw and its biochar addition on soil labile carbon and soil organic carbon. J Integr Agric 13:491-498

Zandstra HG (1982) Effect of soil moisture and texture on the growth of upland crops after wetland rice. In: Report of a workshop on cropping systems research in Asia. IRRI, Los Baños, Philippines

Zhao X, Zhang R, Xue JF, Pu C, Zhang XQ, Liu SL, Chen F, Lal R, Zhang HL (2015) Managementinduced changes to soil organic carbon in China: a meta-analysis. Adv Agron 134:1-50

Open Access This chapter is licensed under the terms of the Creative Commons Attribution 4.0 International License (http://creativecommons.org/licenses/by/4.0/), which permits use, sharing, adaptation, distribution and reproduction in any medium or format, as long as you give appropriate credit to the original author(s) and the source, provide a link to the Creative Commons licence and indicate if changes were made.

The images or other third party material in this chapter are included in the chapter's Creative Commons licence, unless indicated otherwise in a credit line to the material. If material is not included in the chapter's Creative Commons licence and your intended use is not permitted by statutory regulation or exceeds the permitted use, you will need to obtain permission directly from the copyright holder.

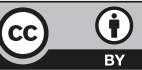

